\title{
Modelling decision support system for selection maahad tafiz center using analytical hierarchal analysis
}

\author{
Abd R Mamat ${ }^{1}$, Mohamad A Mohamed ${ }^{2}$, Amirul F Azhar ${ }^{3}$, Syarilla I A Saany ${ }^{4}$, Norkhairani A Rawi ${ }^{5}$, \\ Maizan M Amin', Mohd F A Kadir ${ }^{7}$, M A M Nor ${ }^{8}$ \\ 1,2,3,4,5,6,7 Faculty of Informatics and Computing, Universiti Sultan Zainal Abidin, Besut Campus, Malaysia \\ ${ }^{8}$ Top IT Industries Sdn Bhd, Lot e-Book Belakang ILP, Kawasan Perindustrian Gong Badak, Malaysia
}

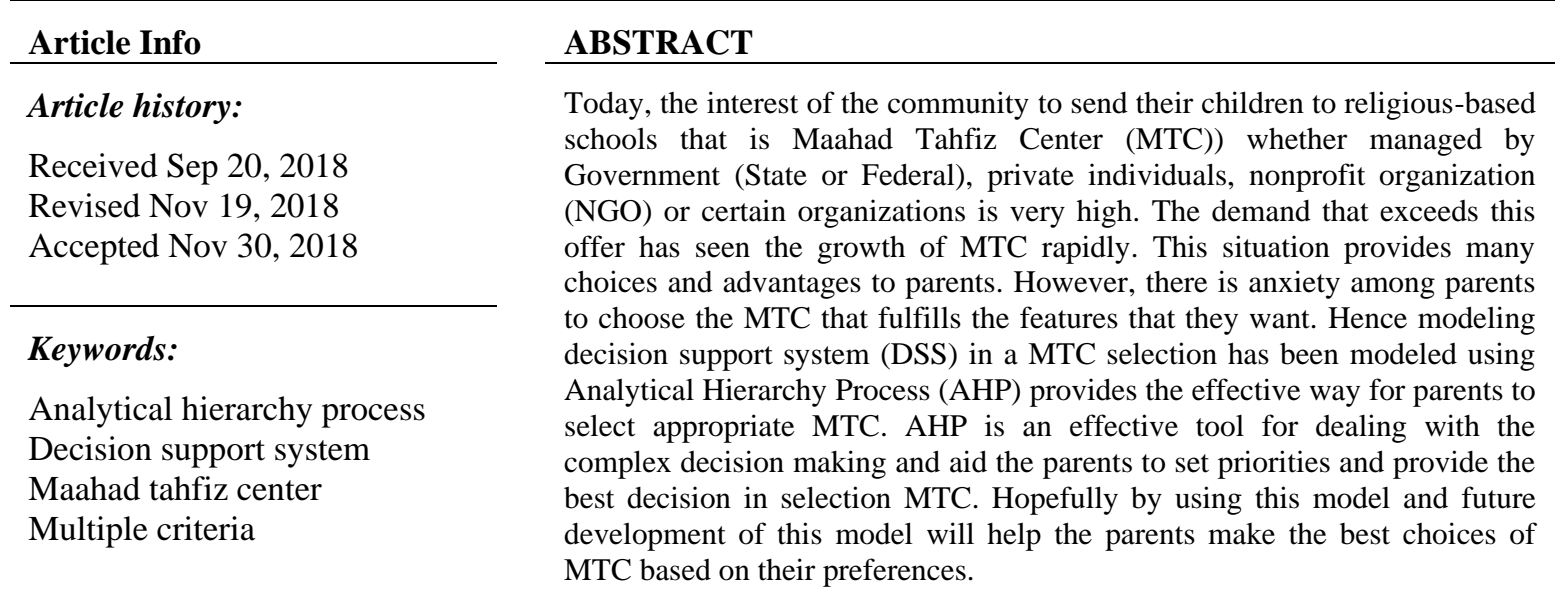

Copyright $(0) 2019$ Institute of Advanced Engineering and Science. All rights reserved.

\section{Corresponding Author:}

Abd R Mamat,

Faculty of Informatics and Computing,

Universiti Sultan Zainal Abidin,

Besut Campus, Malaysia.

Email: arm@unisza.edu.my

\section{INTRODUCTION}

In Malaysia, people's interest in religious education is very high. Parents' requests to send children to religious school known as Maahad Tahfiz Center (MTC) are growing in demands and becoming extremely large, so large than that they can offer. The latest developments show that the way MTC provides the curriculum that includes the memorizing of Al-Quran or the tahfiz Al-Quran began to gain public attention and as such the number of MTC has grown tremendously. What interesting is that each school offers a diverse and distinctive curriculum design and approach. There are also other institutions that offer al-Quran recitation programs, diplomas (after SPM), secondary schools, primary schools, pre-school and child care centers. The goals of the establishment and the implementation methods vary from each other. Some of them give full focus to the aspect of Quranic memorization only, meanwhile some others give a balance to several other components with varying rates other than the Quranic excerpts such as academic studies (offered by the mainstream schools), study of the 'kitab kuning'(turath) in Arabic language at the lodges, science flows, certain skills (such as vocational) and others [1-3].

This diversity is assumed to have different justifications, goals and direction between the various parties involved. First of all, parents have their own goals and justifications regarding the choice of places and types of MTC. Similarly, the individual or organization that established the MTC institution should have their own goals and objectives. The same is happen at the state or federal level, which also offers the MTC 
flow system of the Quran. The expectations and goals between the three parties may be in harmony with each other and may also be different or contradictory to one another.

The justification and direction of the different or perhaps the similarties between the goals of the MTC with the aim of the parents, invites problems to parents in the selection of MTC that meet or suite with their features. Hence, this paper proposes a model that supports the parent's decision making process in selecting the right MTC for their children analytic hierarchy process (AHP) method. To obtain information on MTC, questionaries' methods have been made in several MTC, at the district of Besut, Terengganu. This method is also applied to parents for obtaining the desired characteristics in the selection of MTC.

\section{RELATED WORKS}

Parents have shown a high interest in choosing religious education for their children such that the demand has exceeded the supply and as such this situation cannot be accommodated by religious schools provided by the government. Consequently, this condition encourages parents to choose MTCs which was founded by individuals, organizations or someone who are well-versed with the syllabus based on tahfiz alquran. Due to this, the growth of the MTCs is so rapid [1-2] and this gives parents more options in choosing where to send their children to continue their studies.

The AHP technique has been repetitively studied and adopted into various applications that make use of multiple criteria decision making (MCDM) [4-10]. Some examples of applications are within the domains of education, engineering, government, industry, management, manufacturing, politic, social, and sports [5]. In [11], the authors illustrate the use of AHP at school. It was used to determine the quality of a school (ranking) based on the various criteria.

Subsequently, AHP technique and use of tools for quality development with the aim to improve the quality of industrial engineering at the educational institution [12]. Surveys and interviews were conducted for different groups that are related industrial engineering to obtain user requirements and AHP is used as a tool to prioritize these requirements.

Meanwhile, the author in [13] presented the AHP as a decision making tool that allows the consideration of multiple criteria in decision making procedure. Pre-School education selection system was created to demonstrate the AHP application. The multiple criteria were examined through questionnaires. The Pre-School score was calculated to assess parents' preferences based on criteria and sub criteria. Finally, the Pre-School was ranked based on their scores. The result of this study provides suggestions and directions for Pre-School operators to take appropriate actions in improving their businesses.

\section{MAAHAD TAHFIZ CENTER}

\subsection{Definition of Maahad Tahfiz Center}

According to the [14-15] Maahad (M) is refer as a place or study center of Islam and Tahfiz is a center to memorize and study the Al-Qur'an. By combining of the Maahad and the Tahfiz (MTC), it becomes the center of Islamic Study for memorizing and studying Al-Quran.

\subsection{The attributes of the Maahad Tahfiz Center (MTC) School}

Two separate set of questionnaires were distributed to the parents and MTC School. Parents are experts in knowing and selection the features/attributes of the Tahfiz Center that encourage them to send their children. Information of the Tahfiz Center that are needed encompasses of the learning curriculum, the available facilities and so on. Twenty-five parents with various academic aspects, residences and so on have participated in this questionnaires. Meanwhile four (4) MTC were selected to obtain the information. In some cases, some questions require respondents to select a scale from 1 to 5 with $1=$ very satisfying, 2=satisfying, 3=moderate 4=normal and lastly 5=unsatisfactory. In addition, respondents should state their choice of whether Y-Yes and T-No for specific questions. Table 1 shows the comparison of the attributes/sub attributes collected from the MTCs. In this study, MTC centers are labeled as A, B, C and D (to avoid the use of real names).

\section{DECISION SUPPORT MODEL}

To develop the decision support model, it involves a few steps. Firstly, we understand and structure the problem. The problem faced by parents in choosing or makes decision to select the right MTC that fulfills their features. The purpose is to send their children to pursue their studies there. Feedback from questionnaires as discussed in subsection 3.2 is analyzed and finally is classified into 4 attributes or criteria's and is shown in Table 2. 
Table 1. Comparison of Attributes for MTC

\begin{tabular}{|c|c|c|c|c|}
\hline MTC Attributes & MTC A & MTC B & MTC C & MTC D \\
\hline \multicolumn{5}{|l|}{ General } \\
\hline Year of establishment & 2012 & 2017 & 2010 & 2012 \\
\hline Having a webpage/IG/Facebook & Facebook & Facebook & Facebook & Facebook \\
\hline Location & Rural & Rural & Rural & Rural \\
\hline \multicolumn{5}{|l|}{ Academic } \\
\hline Number of staffs (academic) & 4 & 4 & 5 & 6 \\
\hline Number of staffs (non-academic) & 3 & 2 & 3 & 4 \\
\hline Number of students (active) & 42 & 11 & 36 & 30 \\
\hline Student's Age & $10-20$ & $11-16$ & $10-20$ & $10-18$ \\
\hline Entry requirements & Interviews & Interviews & Interviews & Interviews \\
\hline \multicolumn{5}{|l|}{ Learning time: } \\
\hline $\begin{array}{l}\text { Normal day } \\
\text { Weekend }\end{array}$ & \multicolumn{3}{|c|}{ Weekend } & $5 \mathrm{am}-4.30 \mathrm{pm}$ \\
\hline \multicolumn{5}{|l|}{ Syllabus } \\
\hline Tajwid and Al-Quran Studies & $\mathrm{Y}$ & $\mathrm{Y}$ & $\mathrm{Y}$ & $\mathrm{Y}$ \\
\hline Memorizing Al-Quran & $\mathrm{Y}$ & Y & Y & Y \\
\hline Jawi Studies & $\mathrm{Y}$ & $\mathrm{N}$ & $\mathrm{N}$ & $\mathrm{Y}$ \\
\hline Arab Language Studies & $\mathrm{Y}$ & $\mathrm{N}$ & $\mathrm{Y}$ & $\mathrm{Y}$ \\
\hline Fardu Ain Studies & $\mathrm{Y}$ & $\mathrm{Y}$ & $\mathrm{Y}$ & $\mathrm{Y}$ \\
\hline \multicolumn{5}{|l|}{ Kitab (Books) Studies: } \\
\hline Feqah (name) & Safinatun Najah & $\mathrm{N}$ & $\mathrm{N}$ & $\mathrm{N}$ \\
\hline Tauhid (name) & Risalah Tauhid & $\mathrm{N}$ & $\mathrm{N}$ & $\mathrm{N}$ \\
\hline Tassawuf (name) & Bidayatul- Hidayah & $\mathrm{N}$ & $\mathrm{N}$ & $\mathrm{N}$ \\
\hline \multicolumn{5}{|l|}{ Carrier Path } \\
\hline \multicolumn{5}{|l|}{$\begin{array}{l}\text { Are the students following the } \\
\text { mainstream study (Example - }\end{array}$} \\
\hline School)? & $\mathrm{N}$ & $\mathrm{N}$ & $\mathrm{N}$ & $\mathrm{N}$ \\
\hline $\begin{array}{l}\text { Are the students take public } \\
\text { examinations? }\end{array}$ & $\begin{array}{l}\text { Y-SPM \& STAM } \\
\text { (Link with third party } \\
\text { - Pondok Moden) }\end{array}$ & $\begin{array}{l}\text { Y-SPM } \\
\text { (private) }\end{array}$ & $\begin{array}{l}\text { Y-SPM } \\
\text { (private) }\end{array}$ & Y-SPM (private) \\
\hline Are the students further their study: & MOU Indonesia & $\mathrm{N}$ & $\mathrm{N}$ & $\mathrm{N}$ \\
\hline \multicolumn{5}{|l|}{ IPTA/IPTS } \\
\hline Career opportunities & $\begin{array}{l}\text { Ustaz/imam at the } \\
\text { mosque }\end{array}$ & $\begin{array}{l}\text { Ustaz/imam at } \\
\text { the mosque }\end{array}$ & $\begin{array}{l}\text { Ustaz/imam at } \\
\text { the mosque }\end{array}$ & $\begin{array}{l}\text { Ustaz/imam at } \\
\text { the mosque }\end{array}$ \\
\hline \multicolumn{5}{|l|}{ Facilities -Hostel } \\
\hline All students stay at hostel? & Y & $\mathrm{Y}$ & $\mathrm{Y}$ & $\mathrm{Y}$ \\
\hline $\begin{array}{l}\text { Have a surau for religious } \\
\text { activities? }\end{array}$ & $\mathrm{Y}$ & $\mathrm{Y}$ & $\mathrm{Y}$ & $\mathrm{Y}$ \\
\hline Have a study room (if Y), & $\mathrm{Y}$ & $\mathrm{N}$ & $\mathrm{Y}$ & $\mathrm{Y}$ \\
\hline Condition? & 3 & - & 3 & 3 \\
\hline Condition of the hostel/dorm? (1-5) & 3 & 2 & 2 & 3 \\
\hline \multicolumn{5}{|l|}{ Food and Drink Preparation } \\
\hline How many meals (times) per day? & 3 times & 3 times & 3 times & 3 times \\
\hline \multicolumn{5}{|l|}{ Safety } \\
\hline $\begin{array}{l}\text { Registered with government } \\
\text { agency? }\end{array}$ & Y (Maidam) & Y (Maidam) & Y (Maidam) & Y (Maidam) \\
\hline Safety status provided? & $\begin{array}{l}\text { 2- Near the fire } \\
\text { station }\end{array}$ & 4 & 3 & 3 \\
\hline Functional fire extinguishers? & $\mathrm{Y}$ & $\mathrm{Y}$ & $\mathrm{Y}$ & $\mathrm{Y}$ \\
\hline $\begin{array}{l}\text { Have an emergency route and place } \\
\text { to gather in case of an emergency? }\end{array}$ & $\mathrm{Y}$ & $\mathrm{Y}$ & $\mathrm{Y}$ & $\mathrm{Y}$ \\
\hline $\begin{array}{l}\text { Hold safety awareness talks to } \\
\text { students? } \\
\text { Sport and Recreations }\end{array}$ & $\mathrm{Y}$ & $\mathrm{Y}$ & $\mathrm{Y}$ & $\mathrm{Y}$ \\
\hline $\begin{array}{l}\text { Condition of facilities for students } \\
\text { activity. (1-5) }\end{array}$ & 2 & 2 & 2 & 2 \\
\hline \multirow[t]{3}{*}{ Outdoor activities } & Male-Football Field & Male-Football & Male-Football & Male-Football \\
\hline & Female-Field & Field & Field & Field \\
\hline & & Female-Field & Female-Field & Female-Field \\
\hline \multirow[t]{3}{*}{ Indoor activities } & Place for Qasidah \& & Place for & Place for & Place for \\
\hline & Nasyid & Qasidah \& & Qasidah \& & Qasidah \& \\
\hline & & Nasyid & Nasyid & Nasyid \\
\hline \multicolumn{5}{|l|}{ Fees and Donations } \\
\hline $\begin{array}{l}\text { Lump sum (Tuitions, } \\
\text { accommodation \& food) }\end{array}$ & RM 200 per month & $\begin{array}{l}\text { RM } 240 \text { per } \\
\text { month }\end{array}$ & $\begin{array}{l}\text { RM } 220 \text { per } \\
\text { month }\end{array}$ & $\begin{array}{l}\text { RM } 250 \text { per } \\
\text { month }\end{array}$ \\
\hline Fees paid by students? (1-5) & 2 & 4 & 2 & 3 \\
\hline $\begin{array}{l}\text { Does the center receive funds from } \\
\text { outside? }\end{array}$ & $\begin{array}{l}\mathrm{Y} \text { - individuals and } \\
\text { company }\end{array}$ & $\begin{array}{l}\mathrm{Y} \text { - individuals } \\
\text { and company }\end{array}$ & $\begin{array}{l}\mathrm{Y} \text { - individuals } \\
\text { and company }\end{array}$ & $\begin{array}{l}\mathrm{Y} \text { - individuals } \\
\text { and company }\end{array}$ \\
\hline
\end{tabular}


Table 2. Attributes to Select MTC

\begin{tabular}{ll}
\hline Criteria & \multicolumn{1}{c}{ Explanation } \\
\hline Academic & This attribute refers to the syllabus offered by MTC. It can be divided into sub attributes. \\
Facilities & The facilities provided by MTC centers refer to the facilities provided either in schools or hostels. \\
& This attributes can be divided into sub attributes. \\
Cost & All the fees charged to the students. \\
Location & Location of the MTC, either urban or rural. \\
\hline
\end{tabular}

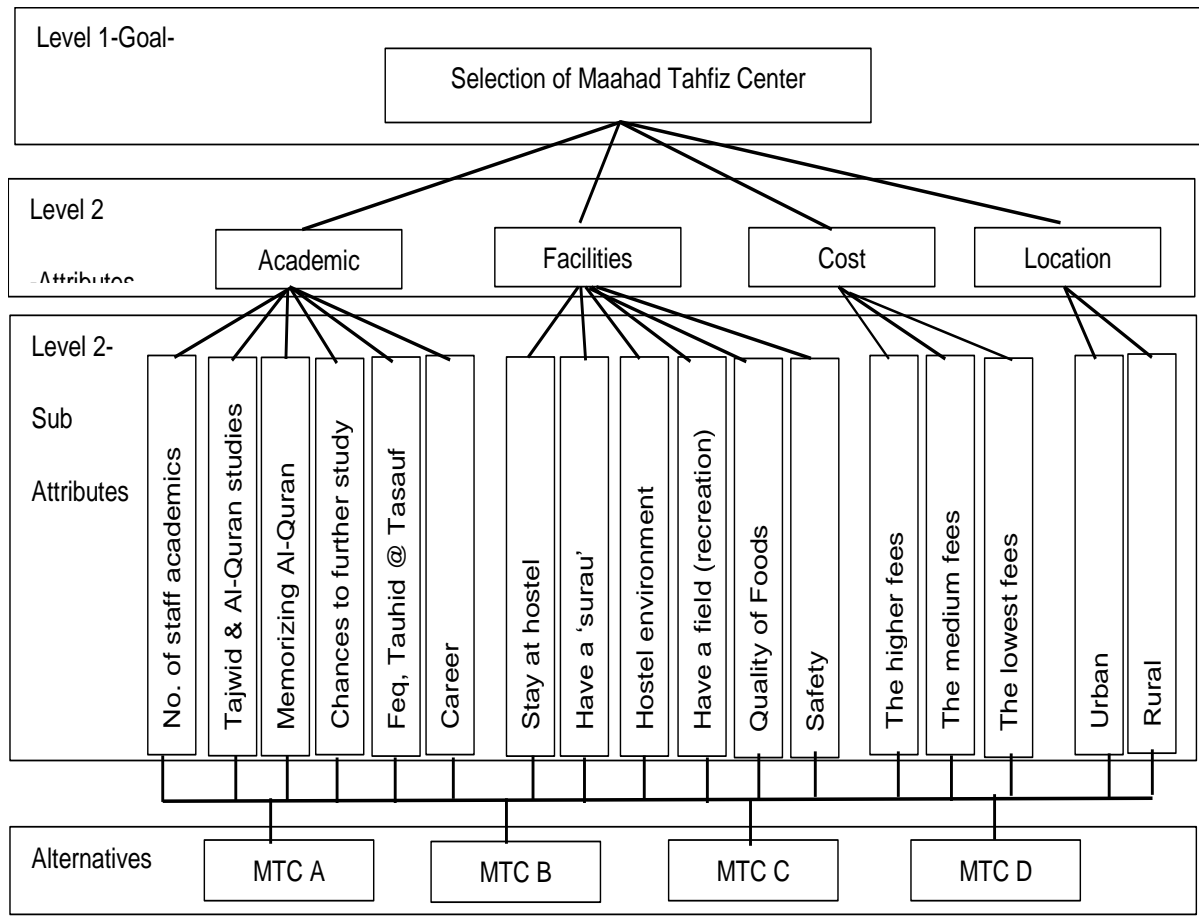

Figure 1. The hierarchy of modelling MTC

The problem is structured based on hierarchy diagram, where the top represent the goal, followed by attributes (criteria) at second level and third level represents sub attributes/sub-criteria and the lowest level is alternatives. This hierarchy diagram is represented in Figure 1.

Table 3. The Degree of Importance

\begin{tabular}{cc}
\hline Scale & Explanation \\
\hline 1 & Equal importance \\
2 & Weak \\
3 & Moderate Importance \\
4 & Moderate Plus \\
5 & Strong Importance \\
6 & Strong Plus \\
7 & Very Strong \\
8 & Very-very Strong \\
9 & Extreme Importance \\
\hline
\end{tabular}

Secondly, we compute the priority. A priority is a score that ranks of the importance of the criteria (attributes) in made decision. In AHP, it uses pairwise comparison and generally is evaluated on 1-9 scale [16]. We compare each element in the corresponding level and calibrate them on the numerical. Table 3 shows the scale of comparison.

The comparison is collected in a matrix form that is pairwise comparison between the criteria, and an example is shown in Table 4 and named as A matric. 
Table 4. Comparison Matrix (A)

\begin{tabular}{lcccc}
\hline & Criteria 1 & Criteria 2 & Criteria 3 & Criteria N \\
\hline Criteria 1 & $a_{i j}$ & $a_{i j+1}$ & $a_{i j+2}$ & $a_{i j+n}$ \\
Criteria 2 & $a_{i+1 j}$ & $a_{i+1 j+1}$ & $a_{i+1 j+2}$ & $a_{i+1 j+n}$ \\
Criteria 3 & $a_{i+2 j}$ & $a_{i+2 j+1}$ & $a_{i+2 j+2}$ & $a_{i+2 j+n}$ \\
Criteria N & $a_{i+n j}$ & $a_{i+n j+1}$ & $a_{i+n j+2}$ & $a_{i+n j+n}$ \\
\hline
\end{tabular}

The number of comparisons for each matrix can be computed using (1).

$$
\frac{n^{2}-n}{2}
$$

Where $n$ is number of attributes (criteria).

In Table 4, Comparison matric, $\boldsymbol{A}$, suppose the entry $a_{i j}$ in the $i$ th row and the $j$ th column of this matric. Each entry $a_{i j}$ of the matric $\boldsymbol{A}$, show the importance of the $i$ th criterion relative to $j$ th creation. It can be concluded that, if $a_{i j}>1$, means that the $i$ th criterion is more important compare the $j$ th criterion and vice versa. If $a_{i j}=1$, it represents the criterion is same important. Matrix $\boldsymbol{A}$, also reciprocal, that is why only half comparison are required and main diagonal is 1 because it's compare to itself.

Next, normalized pairwise comparison Matrix $\boldsymbol{A}$ using (2) and sum of the entries on each column equal to 1

$$
\overline{a_{\imath \jmath}}=\frac{a_{i j}}{\sum_{t=1}^{n} a_{t j}}
$$

Where $n$ number of column (criteria).

It is followed by calculating criteria weight $(w)$, by averaging the entries on each row. (3) is used to calculate this value.

$$
w_{j}=\frac{\sum_{t=1}^{n} \overline{a_{l t}}}{n}
$$

Since it is normalized, the sum of all elements $w$ is 1 . The priority $w$ shows relative weights among the factors that we compare.

The third steps are consistency check followed by sensitivity analysis. This step is optional but this is important for confirming the robustness of the results. In this step, we check the consistency by computing the consistency index (CI), using (4).

$$
C I=\frac{\gamma_{\max }-n}{n-1}
$$

Where $\gamma_{\max }$ is the maximal eigenvalue, and thus consistency ratio (CR) is given by

$$
C R=\frac{C I}{R I}
$$

Where $R I$ is the random index. If $C R$ is less than $10 \%$ then the matrix is of an acceptable consistency. Table 5 shows the $R I$ [17].

Table 5. Random Indices $(R I)$

\begin{tabular}{lllllllll}
\hline$n$ & 3 & 4 & 5 & 6 & 7 & 8 & 9 & 10 \\
\hline$R I$ & 0.58 & 0.9 & 1.12 & 1.24 & 1.32 & 1.41 & 1.45 & 1.49 \\
\hline
\end{tabular}

where $\mathrm{n}$ is number of attribute (criteria).

The final step of the decision process is the sensitivity analysis, where input data of the scenario is modified. Observation is made on the results whether there is any implication or not. Process sensitivity analysis allows using different scenarios to be generated. These different scenarios may result in other rankings, and further discussion may be needed to reach a consensus. If the ranking does not change, the results are said to be robust - otherwise they are sensitive. 


\section{CONCLUSION AND FUTURE WORKS}

The selection of the Tahfiz Center that conforms to the taste of parents is one of the crucial criteria. Proper selection ensures the learning process can run effectively and the resulting student can memorize AlQuran and have a high personality character. The proposed multi-criteria selection model is expected to help parents identify the best MTC. For future recommendations, the implementation of this model will be tested by the experts (parent and MTC). We also refine the decision attributes (criteria) and sub attributes in detail to make sure the robustness of this model and finally give the best choice for parents in the MTC selection.

\section{ACKNOWLEDGEMENTS}

This project is partially funded by the Research Management, Innovation \& Commercialization Center, Universiti Sultan Zainal Abidin.

\section{REFERENCES}

[1] Nawi, N. H. M., Yusuff, N. A., Yaacob, M. B. C., \& Salleh, N. H. (2014). "Matlamat dan halatuju sistem pengajian tahfiz di Kelantan: satu pengamatan awal". In: 4th International Conference and Exhibition on Islamic Education (ICIEd 2014), 31 May - 2nd June 2014, Perdana Hotel, Kota Bharu, Kelantan. (Unpublished).

[2] Abdullah, M., Abdullah, A. H., Rosman, A. S., Islam, F. T., \& Ilias, M. F(2015. "Pendidikan Tahfiz di Malaysia: Satu Sorotan Sejarah". Seminar International Conference on Education and Social Entrepreneurship 2015,

[3] Shaffie, F. (2001). "Institusi pondok di Malaysia: satu sorotan dari perspektif sejarah". Jurnal Pembangunan Sosial, 2, 116-132.

[4] Saaty, T. L. "The Analytic Hierarchy Process", McGraw-Hill, New York, 1980. There is no corresponding record for this reference.

[5] Vaidya, O. S., \& Kumar, S. (2006). "Analytic hierarchy process: An overview of applications". European Journal of operational research, 169(1), $1-29$.

[6] Xiaodi, W., \& Xiuyan, P. (2011, May). "Application of analytic hierarchy process in evaluating education equipment efficiency factors". In, 2011 International Conference on (Vol. 1, pp. 96-100).IEEE.

[7] Fadhilah Ahmad and M Yazid M Saman. 2011. "Application Of Integrated Decision Support Model In Tendering, Recent Trends in Wireless and Mobile Networks Communications in Computer and Information Science", Volume 162, Part 4, 406-413, DOI: 10.1007/978-3-642-21937-5_39, Lecture Notes (LNCS), Springer-Verlag Berlin Heidelberg. Presented in WiMo/CoNeCo 2011, Communications in Computer and Information Science (CCIS) 162, pp. 406-413, 2011.

[8] Fadhilah Ahmad and M Yazid M Saman. 2011. "Integrated Decision Support Model for Construction Project Tendering”, Journal of Computing, 3: 6, ISSN 2151 -9617.

[9] Gupta, S., Dangayach, G. S., Singh, A. K., \& Rao, P. N. (2015). "Analytic hierarchy process (AHP) model for evaluating sustainable manufacturing practices in Indian electrical panel industries". ProcediaSocial and Behavioral Sciences, 189, 208-216.

[10] Bevilacqua, M., \& Braglia, M. (2000). "The analytic hierarchy process applied to maintenance strategy selection". Reliability Engineering \& System Safety, 70(1), 71 -83.

[11] Badri, M., Al Qubaisi, A., Mohaidat, J., Al Dhaheri, H., Yang, G., Al Rashedi, A., \& Greer, K. (2016). "An analytic hierarchy process for school quality and inspection: Model development and application". International Journal of Educational Management, 30(3), 437-459.

[12] Lam, K., \& Zhao, X. (1998). "An application of quality function deployment to improve the quality of teaching". International Journal of Quality \& Reliability Management, 15(4), 389-413.

[13] Mamat, A. R., Rasid, N. H. A., Ahmad, F., Rawi, N. A., Mohamed, M. A., Awang, W. S. W., \& Ghazali, F. (2017, October). "Pre school selection system using Analytic Hierarchy Process (AHP): Implementation and usability study". In Automatic Control and Intelligent Systems (I2CACIS), 2017 IEEE 2nd International Conference on (pp. 7-12). IEEE.

[14] Aziah, T., \& Mohd. F. Kamus Pelajar Edisi Kedua, (2016), Kuala Lumpur, Dewan Bahasa dan Pustaka

[15] Noresah, B. Kamus Dewan Edisi Keempat (2007), Kuala Lumpur, Dewan Bahasa dan Pustaka

[16] Ishizaka, A., \& Nemery, P. (2013). "Multi-criteria decision analysis: methods and software". John Wiley \& Sons.

[17] Saaty, T. L. (1977). "A scaling method for priorities in hierarchical structures". Journal of mathematical psychology, 15(3), 234-281. 